Vol. 11 (3): 441-448 (2021)

\title{
REACTION OF SOME NEW WHEAT LINES IN THE CONDITIONS OF TWO CULTIVATION AREA, LUSHNJE (ALBANIA), AND ISTOG (KOSOVO)
}

\author{
Nazmi Hasanaj ${ }^{12}$, Arsim Elshani ${ }^{1 *}$, Artan Sota ${ }^{3}$ \\ ${ }^{1 *}$ University of Haxhi Zeka, Faculty of Agribusiness, Peja, Kosovo; \\ ${ }^{2}$ Seed Factory "Koal Seeds", Istog, Kosovo; \\ ${ }^{3}$ Agricultural University of Tirana, Faculty of Agronomy and Environment, Tirana, Albania; \\ Corresponding Author Arsim Elshani, e-mail: arsim.elshani@unhz.eu;
}

Received March 2021; Accepted April 2021; Published May 2021;

DOI: https://doi.org/10.31407/ijees11.311

\begin{abstract}
The aim of this paper provides data on the behaviour of some new soft wheat lines created by Agroarfa (Albania), in two cultivation environments, respectively in Lushnje (Albania) and Istog (Kosovo). From the yield data of the lines result noticeable changes in terms of average yield, as well as from line to line. Some of the lines like; AF19-65 and AF-08 do not show significant differences between the two test areas, which shows that these are characterized by a better stability in terms of production. Generally, the lines with higher yields such as AF19-64, AF19-06, etc., are characterized by more pronounced differences between areas
\end{abstract}

Keywords: index, line, randomization, stability, variation. 